マウス

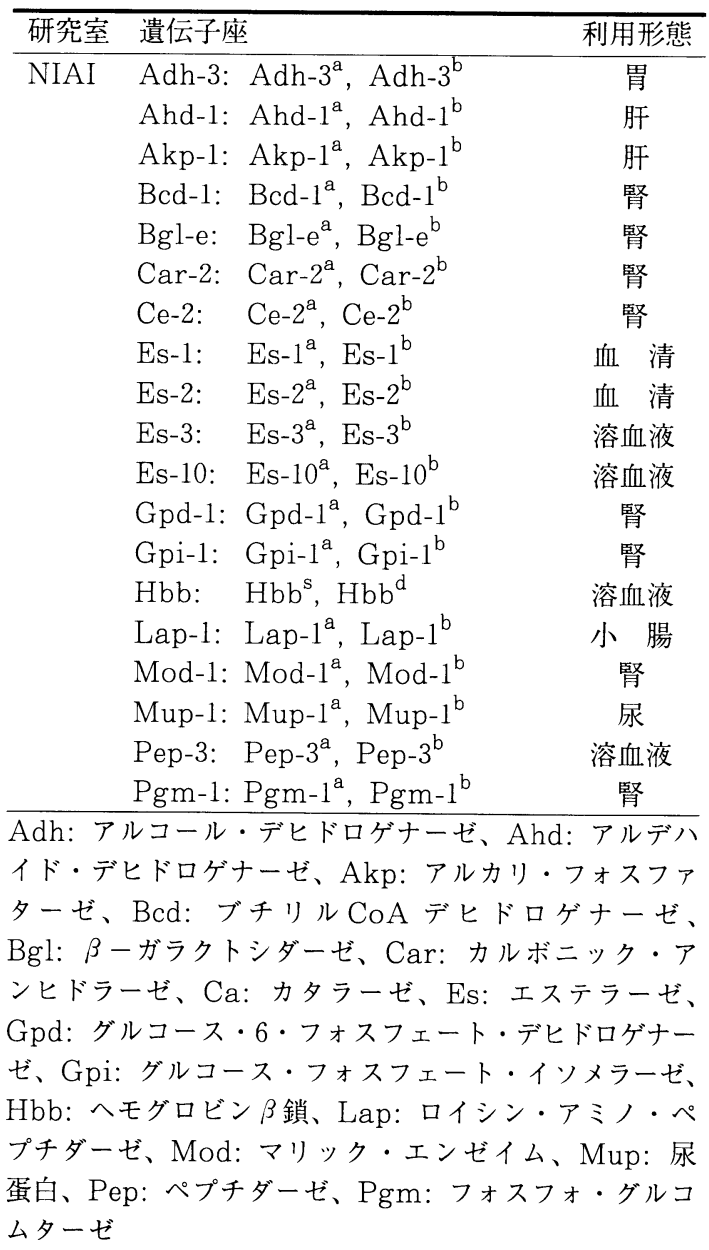

国内における研究用特殊系統のリスト

\section{List of the Specific Lines for Immunogenetic Studies}

\section{特殊系統維持機関とその略号}

$\mathrm{H}$ : 広島大学生物生産学部家畜育種学教室（岡田育

穂）恶724 東広島市西条町大字下見

天 0824 (22) 7111

NIAI：農林水産省畜産試験場育種部（三上仁志、大石 孝雄）=305 茨城県筑波農林研究団地内局私書 箱5号、80298（38）8624、8622

NIBS：日本生物科学研究所附属実験動物研究所（水谷 誠）拜409-16 山梨県北巨摩郡小淵沢町笹尾 $3331-114$ 。 $055136-2333$

鶏

\begin{tabular}{llll}
\hline 研究室 /品 & 種 /系統 & 特 & 色 \\
\hline $\mathrm{H}$ & &
\end{tabular}

白色レグホン GVHR-H, GVHR-L

移植片対宿主反応態選抜系統（H: 高方向、

$\mathrm{L}$ : 低方向)、共にB座位ホモで $\mathrm{B}^{\mathrm{A}} \mathrm{B}^{\mathrm{A}}$ または $\mathrm{B}^{\mathrm{G}} \mathrm{B}^{\mathrm{G}}$ 、

岡田 ·三上、Brit. Poult. Sci., 15:1-10, 1984.

NIAI

ファイオミ通風系（血中尿酸值高系統）

小宮山、家禽会誌 14: 15-18, 1977.

NIBS

白色レグホン WL-M/O

$\mathrm{SPF}$ 、ニワトリ白血病ウイルス関係 : $\mathrm{C} / 0$, gg

白色レグホン WL-M/BE

$\mathrm{SPF} 、$ ニワトリ白血病ウイルス関係 : $\mathrm{C} / \mathrm{BE}$, gg

白色レグホン WL-F

$\mathrm{SPF}$ 、ニワトリ白血病ウイルス関係 : $\mathrm{C} / 0$, hh, gg

PHAに対する凝集性 : pnpn, phph, tq 1 tq 1 , st1st1, St2St2, pwlpw1, pw2pw2, mplmpl, atat, VaVa, 
鶏

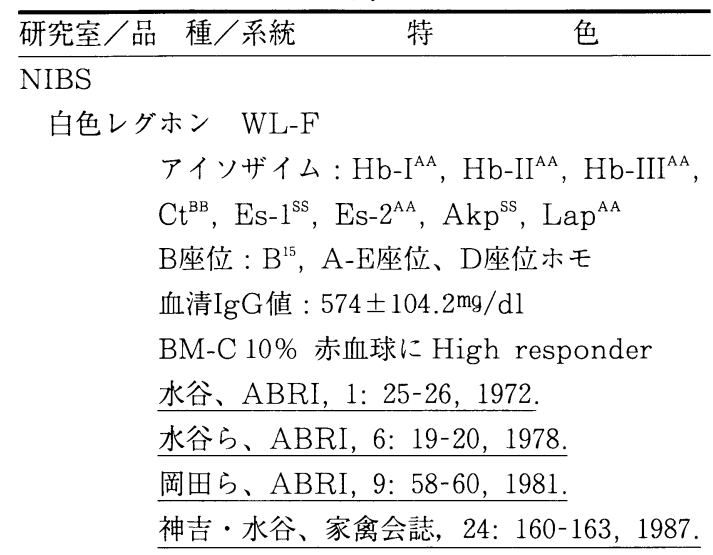

白色レグホン WL-GM

ニワトリ白血球ウイルス関係: C/0, hh, gg PHAに対する凝集性：PnPn, phph, SiSi, tq1tq1, tq2tq2, st1st1, St2St2, pwlpw1, Pw2Pw2, mplmpl, mp2mp2, atat, $\mathrm{VaVa}$, アイソザイム : Hb-I ${ }^{\mathrm{AA}}, \mathrm{Hb}-\mathrm{II}^{\mathrm{AA}}, \mathrm{Hb}-\mathrm{III}^{\mathrm{AA}}$, $\mathrm{Ct}^{\mathrm{BB}}, \mathrm{Es}^{\mathrm{SS}}{ }^{\mathrm{SS}}, \mathrm{Es}^{-2^{\mathrm{AA}}}, \mathrm{Akp}^{\mathrm{SS}}, \mathrm{Lap}^{\mathrm{AA}}$

B座位 : $\mathrm{B}^{15} \mathrm{~B}^{15}$, A-E座位木モ

抗ウズラ赤血球ニワトリ血清に陽性

血清IgG值 : $1263 \pm 236.6 \mathrm{mg} / \mathrm{dl}$

BSAによるアナフラキシーショック死をお こしにくい

水谷ら、ABRI, 7: 24-27, 1979.

ブラックミノルカ BM-C

ニワトリ白血球ウイルス関係: $\mathrm{C} / \mathrm{AE}, \mathrm{HH}$ PHAに対する凝集性：PnPn, phph，sisi， tq1tq1, St1St1, st2st2, pw1pw1, Pw2Pw2, mplmpl, atat, vava,

アイソザイム : Hb-I ${ }^{\mathrm{AA}}, \mathrm{Hb}-\mathrm{II}^{\mathrm{AA}}, \mathrm{Hb}-\mathrm{III}^{\mathrm{AA}}$, $\mathrm{Ct}^{\mathrm{BB}}, \mathrm{Es}^{\mathrm{SS}}{ }^{\mathrm{SS}}, \mathrm{Es}^{-2^{\mathrm{AA}}}, \mathrm{Akp}^{\mathrm{SS}}, \mathrm{Lap}^{\mathrm{AA}}$ B座位 : $\mathrm{B}^{15} \mathrm{~B}^{15}, \mathrm{~A}-\mathrm{E}$ 座位、A-E座位木モ 血清 $I g G$ 值 : $534.6 \pm 134.7 \mathrm{mg} / \mathrm{dl}$

藤尾・水谷·遺伝誌、50: 393-401, 1975.

ファイオミ $\mathrm{PNP}$

ニワトリ白血球ウイルス関係 : C/BE, $\mathrm{HH}$

PHAに対する凝集性: PnPn, phph, tq1tq1, St1St1, st2st2, pwlpw1,

Mp1Mp1, Mp2Mp2, atat, $\mathrm{VaVa}$,

アイソザイム : Hb-I ${ }^{\mathrm{AA}}, \mathrm{Hb}-\mathrm{II}^{\mathrm{AA}}$, Hb-III ${ }^{\mathrm{AA}}$, $\mathrm{Ct}^{\mathrm{BB}}, \mathrm{Es}_{\mathrm{s}} 1^{\mathrm{SS}}, \mathrm{Es}-2^{\mathrm{AA}}, \mathrm{Akp}^{\mathrm{SS}}, \mathrm{Lap}^{\mathrm{AA}}$
鵎

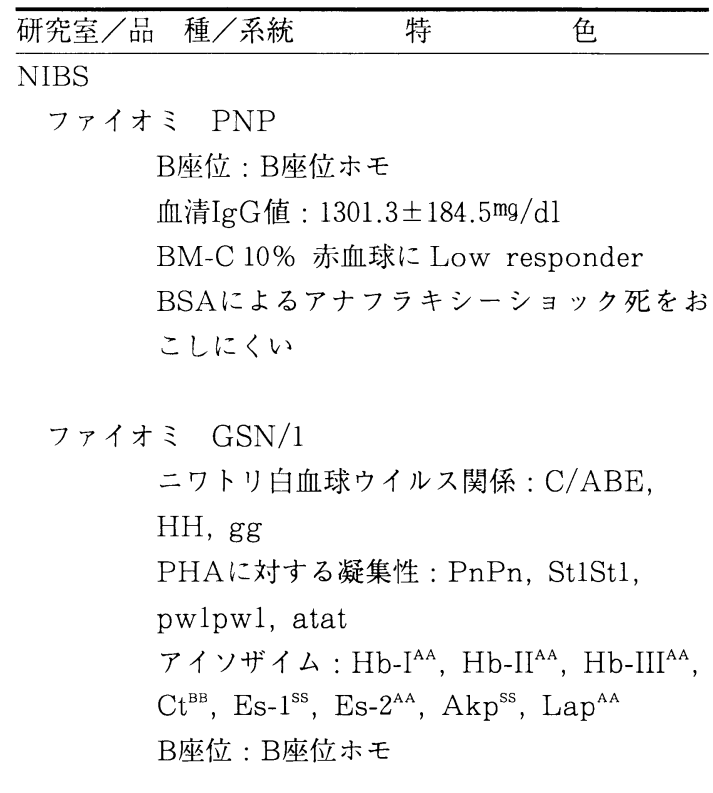

ファイオミ $\mathrm{GSN} / 2$

ニワトリ白血球ウイルス関係 : $\mathrm{C} / \mathrm{ABE}$,

$\mathrm{HH}$, gg

PHAに対する凝集性 : PnPn, St1St1,

Tq1Tq1

アイソザイム : Hb-I ${ }^{\mathrm{AA}}, \mathrm{Hb}-\mathrm{II}^{\mathrm{AA}}, \mathrm{Hb}-\mathrm{III}^{\mathrm{AA}}$, $\mathrm{Ct}^{\mathrm{BB}}, \mathrm{Es}-^{\mathrm{sS}}, \mathrm{Es}_{\mathrm{s}} 2^{\mathrm{AA}}, \mathrm{Akp}^{\mathrm{SS}}, \mathrm{Lap}^{\mathrm{AA}}$

B座位 : B座位ホモ

GSN/1とは同種免疫抗血清5517（C座位と 思われる）に対する凝集性が異なる。

ファイオミ GPS

ニワトリ白血球ウイルス関係 : $\mathrm{C} / \mathrm{ABE}$,

$\mathrm{HH}, \mathrm{GG}$

PHAに対する凝集性: pnpn, phph, tqltq1, St1St1, PwlPwl, mplmpl, atat, $\mathrm{VaVa}$ アイソザイム : Hb-I ${ }^{\mathrm{AA}}, \mathrm{Hb}-\mathrm{II}^{\mathrm{AA}}, \mathrm{Hb}-\mathrm{III}^{\mathrm{AA}}$, $\mathrm{Ct}^{\mathrm{BB}}, \mathrm{Es}-1^{\mathrm{SS}}, \mathrm{Es}-2^{\mathrm{AA}}, \mathrm{Akp}^{\mathrm{SS}}, \mathrm{Lap}^{\mathrm{AA}}$

B座位 : B座位ホモ

血清IgG值 : $1003.4 \pm 204.5 \mathrm{mg} / \mathrm{dl}$

BSAによるアナフラキシーショック死をお こしやすい

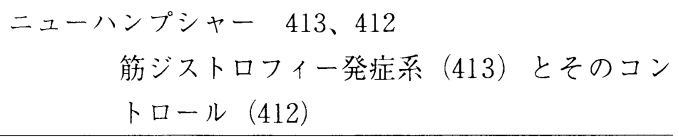

筋ジストロフィー発症系 (413) とそのコン トロール (412) 
鶏

\begin{tabular}{lll}
\hline 研究室 /品 種/系統 & 特 \\
\hline
\end{tabular}

NIBS

$$
\text { ファイオミ GSN/2am }
$$

筋ジストロフィー発症系、

B座位ホモ（GSN/2と同じ）

ファイオミ $\mathrm{AN}$

神経異常発症系

Nunoya et al., Lab. Anim., 17: 298-302 1983.

ファイオミ YL

delayed amelanosis 発症系、自己免疫性 と思われる甲状腺炎発症

ファイオミ $\mathrm{PNP} / \mathrm{DO}$

double oviducts 系

ファイオミ $\mathrm{PNP} / \mathrm{NV}$

無声

白色レグホン WL-G/am

筋ジストロフィー発症系

白色レグホン WL-15G

翼下静脈走行異常系

白色レグホン PNN

PHAに対する凝集性 : pnpn, SnSn, nsns

水谷ら、日畜会報、48: 463-467，1977.

血液型： $\mathrm{Ly}_{2} \mathrm{Ly}_{2} 、$ Kato, H. \& Wakasugi,

N., Immunogenetics, 13: 109-114. 1981.

AEVにより赤芽球症および血管腫が誘発さ

れやすい、Morikawa, et al., Jpn. J.

Med. Sci. Biol., 37: 105-116. 1984.

白色レグホン SBPP

PHAに対する凝集性：snsn, NsNs

血液型 : $\mathrm{Ly}_{2} \mathrm{Ly}_{2}$ 、

羽装：パンダ

水谷ら、日畜会報、48: 227-234. 1977

水谷ら、ABRI，9: 43-45. 1981
鵎

\begin{tabular}{lll}
\hline 研究室/品 & 種/系統 特 \\
\hline NIBS & &
\end{tabular}

白色レグホン SBPN

PHAに対する凝集性：snsn, nsns

血液型: $\mathrm{Ly}_{2} \mathrm{Ly}_{2}$ 、

羽装：パンダ

白色レグホン PSN

PHAに対する凝集性：snsn, SnSn, psps, htht, Es-D ${ }^{b b}$ 、羽装 : パンダ

水谷ら、ABRI，9:43-45，1981

白色レグホン CWE

PHAに対する凝集性 : $\mathrm{SnSn}, \mathrm{NsNs}$

羽装：シナモン、白卵

白色レグホン AMRP

PHAに対する凝固性：NsNs, SnSn,

Es- $D^{\text {aa }}$

血液型 : $\mathrm{Ly}_{3} \mathrm{Ly}_{3}$

マウス赤血球に対する自然凝集素所有形質に

選抜、羽装 : パンダ

白色レグホン TKP

PHAに対する凝集性：SnSn, NsNs, Es-D $D^{\text {bb }}$

血液型: $\mathrm{Ly}_{3} \mathrm{Ly}_{3}$ 、

白色レグホン $\mathrm{CR}$

行動異常系

白色レグホン $R W$

糖原病 II 型発症系、血液型 : $\mathrm{Ly}_{1} \mathrm{Ly}_{1}$ 、

白色レグホン $\mathrm{SHV}$

ミエリン形成異常系 


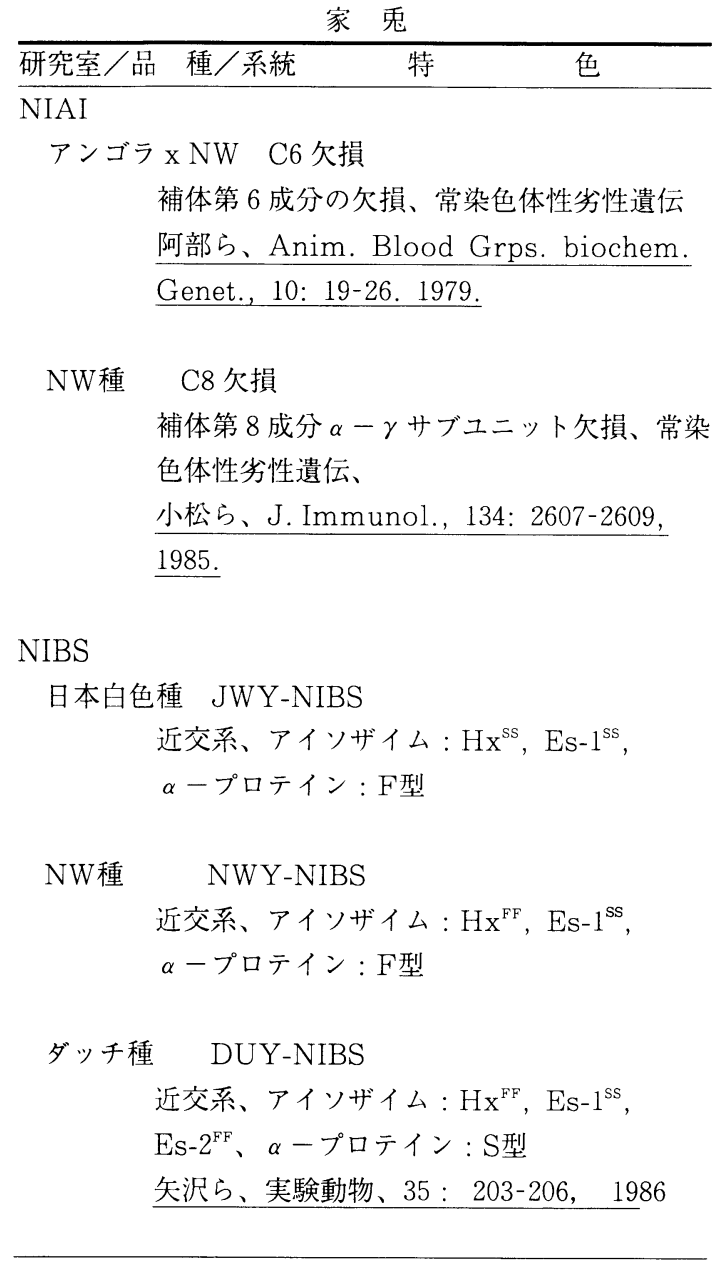

\section{会員による動物血液型および 蛋白多型関係文献}

\author{
List of Contributions by \\ the Members on Animal Blood \\ Groups and Protein Polymorphisms
}

\section{【牛関係】}

森田光夫 ・印牧美佐生、1989. ウシリンパ球（BoLA） に対する同種抗体の検索と特異性、日畜会報、60: 442-449.

芝田 猛・森友靖生・阿部恒男、1989. ウシ染色体相互 転座の 1 症例。日畜会報、60: 686-688.

Tsuji, S., Y. Hirata, \& K. Matsuoka, 1989. Two apparent molecular forms of bovine lactoferrin. J. Dairy Sci., 72: 1130-1136.

Tsuji, S., Y. Sadamitsu, \& N. Goto, 1989. Ultrathin-layer isoelectric focusing for bovine serum transferrin phenotyping. Biochem. Genet. 27: 425-429.

Mukai, F., S. Tsuji, K. Fukazawa, S. Ohtagaki, \& Y. Nambu,1989. History and population structure of a closed strain of Japanese Black cattle. J. Anim. Breed. Genet., 106: 254-264.

\section{【馬関係】}

横濱道成・渡邊泰子 - 小林悦子 - 庄武孝義 - 野沢 謙 茂木一重、1989. 馬の transferrin 型および esterase 型の分類.日畜会報、60：115-120.

横濱道成 · 天野 卓・茂木一重、1989. 二次元電気泳動 法による馬乳蛋白質の同定分布図および沁乳期間に おける経時的変化. 日畜会報、60：450-458.

\section{【豚関係】}

Kurosawa, Y., K. Tanaka, T. Tomita, M. Katsumata, J. S. Masangkay \& A. Q. Lacuata, 1989. Blood groups and biochemical polymorphisms of Warty (or Javan) pigs, Bearded pigs and a hybrid of domestic $x$ Warty pigs in the Philippines. Jpn. J. Zootech. Sci., 60: $57-69$.

Mikami, H., A. Ohnishi, M. Komatsu, \& T. Akita, 1989. Enzyme activity of the mitochon- 